\title{
Regeneration of black ash (Fraxinus nigra Marsh.) in hardwood swamps of the Great Lakes - St. Lawrence Forest Region
}

\author{
by Amanda Springer ${ }^{1}$ and Jeffery P. Dech ${ }^{1 *}$
}

\begin{abstract}
An inductive, ordination-based approach was used to explore patterns in the microenvironment and natural regeneration of black ash across a range of representative stands in the central Ontario portion of the Great Lakes -St. Lawrence Forest Region (GLSL) near Lake Nipissing, Ontario, Canada. The objective of this study was to describe patterns of regeneration of black ash and determine the associations between multiple indicators of black ash regeneration success and biotic and abiotic factors. Using a randomized sampling design with specific selection criteria, 12 black ash stands were sampled, each with three $400 \mathrm{~m}^{2}$ circular sample plots that contained three $4 \mathrm{~m}^{2}$ sub-plots. A suite of environmental variables such as elevation, topographic wetness index, slope, and soil characteristics (percent moisture, $\mathrm{pH}$, total nitrogen, exchangeable phosphorus, potassium, magnesium) were determined for each stand. Variables capturing regeneration potential, including density, diameter, and height of all germinants, seedlings, saplings and sprouts were also collected. A sample of 15 dominant or co-dominant trees in each stand, as well as numerous black ash seedlings, saplings and sprouts were examined using dendrochronological methods to estimate ages. Principal component analysis ordinations were performed exploring the variation in environment and black ash regeneration variables among the stands. High soil moisture and the presence of canopy gaps, (as indicated by high standard deviation of canopy closure), were key variables associated with greater abundance of regeneration. Black ash was the dominant species in all stands, which were also generally characterized by a common reverse-J diameter distribution. It was observed that black ash in the sapling layer reached substantial ages (up to 60 years), indicating they are capable of withstanding long periods of suppression below the canopy. Collectively, these findings suggest that black ash-dominated stands in the study area are regenerating in multiple cohorts. Based on these patterns, it appears that regeneration in these stands is occurring through gap-phase mechanisms, suggesting single tree selection as the best management option for black ash in the GLSL.
\end{abstract}

Keywords: black ash, regeneration niche, ordination, community ecology, gap dynamics.

\section{RÉSUMÉ}

On a adopté une approche systématique par raisonnement inductif pour étudier les caractéristiques du micro-environnement et de la régénération naturelle chez le frêne noir; le territoire visé comprenait une série de peuplements représentatifs de la partie centrale ontarienne de la région des Grands Lacs et du Saint-Laurent (GLSL) près du lac Nipissing en Ontario, au Canada. Cette étude avait pour but de décrire les patrons de régénération du frêne noir et d'établir les liens entre les nombreux indicateurs de succès de sa régénération et les facteurs abiotiques. À partir d'un dispositif d'échantillonnage aléatoire comportant plusieurs critères de sélection, nous avons échantillonné 12 peuplements de frêne noir au moyen de placettes circulaires de $400 \mathrm{~m}^{2}$ comportant trois sous-placettes de $4 \mathrm{~m}^{2}$. Ainsi, pour chaque peuplement, on a observé une série de paramètres environnementaux comme l'élévation, l'indice topographique d'humidité, la pente et les propriétés du sol (pourcentage d'humidité, $\mathrm{pH}$, azote total, phosphore échangeable, potassium, magnésium). On a également mesuré les variables indicatrices du potentiel de régénération dont la densité, le diamètre et la hauteur de l'ensemble des germinats, des semis, des gaules et des pousses. On a également prélevé dans chaque peuplement un échantillon de 15 arbres de l'étage des dominants ou des codominants ainsi que plusieurs semis, gaules et pousses de frêne noir afin d'en établir l'âge par dendrochronologie. L'ordination par les composantes principales a permis d'établir des liens entre les changements d'environnement et les paramètres de régénération du frêne noir dans les peuplements. On a ainsi constaté que l'humidité du sol et la présence de trouée dans la canopée (reflétée par la forte déviation standard affectant la fermeture du couvert) avaient une influence déterminante expliquant la plus forte abondance de la régénération. Le frêne noir était l'essence dominante dans tous les peuplements qui montraient également une distribution des diamètres en J inversé. On a aussi observé dans l'étage des gaulis que les gaules atteignait un âge important (jusqu'à 60 ans) montrant qu'ils peuvent supporter de longues périodes de suppression sous le couvert principal. L'ensemble de ces constatations suggèrent que les peuplements à dominance de frêne noir du secteur à l'étude se régénèrent en une multitude de cohortes. Ces patrons de régénération montrent que ces peuplements se régénèrent à la faveur d'une trouée dans la canopée et suggèrent qu'il serait préférable d'exploiter le frêne noir avec la méthode du jardinage par pied d'arbre dans la région des GLSL.

Mots-clés : frêne noir, niche de régénération, ordination, écologie des communautés, dynamique des trouées

${ }^{1}$ Department of Biology and Chemistry, Nipissing University, 100 College Dr., North Bay, ON, Canada P1B 8L7; ${ }^{\star E m a i l}$ : jeffreyd@nipissingu.ca 


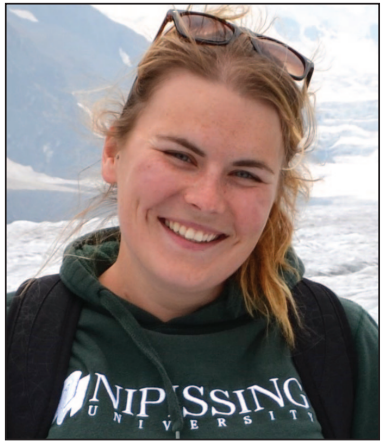

Amanda Springer

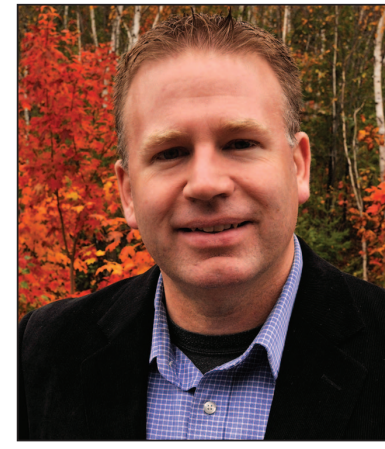

Jeffery P. Dech

\section{Introduction}

Populations of black ash (Fraxinus nigra Marsh.) in the central Ontario portion of the Great Lakes-St Lawrence Forest Region (GLSL) are relatively uncommon or comprise small pockets within larger forest types, which are often overlooked in forest inventories. Generally, across its range black ash occurs in pure stands in nutrient rich swamps that are seasonally flooded or poorly drained and wet throughout the growing season (Erdmann et al. 1987; Tardif et al. 1994). Black ash is also associated with other species on less hydric sites or found growing in small pockets where surface depressions cause pooling of water (Erdmann et al. 1987; Kurmis and Kim 1989). In forested wetlands where black ash forms pure stands, and few other hardwood tree species can establish, the species occupies an important ecological role providing habitat and forage for birds, small mammals, white-tailed deer (Odocoileus virginianus Zimmermann) and moose (Alces alces L.) (Ward et al. 2006; Benedict and Frelich 2008; Palik et al. 2011). Black ash canopies also provide regulation of moisture and light regimes (Kashian and Witter 2011; Slesak et al. 2014; Telander et al. 2015). Additionally, black ash swamps are the most common habitat of flooded jelly skin, Leptogium rivulare Ach. (Mont.), a threatened lichen species in Ontario (Lee 2004).

The arrival of the emerald ash borer (Agrilus planipennis Fairmaire) in North America has stimulated new interest in the ecological, sociological, cultural and economic significance of black ash (Palik et al. 2011; Costanza et al. 2017). Emerald ash borer (EAB) is an invasive pest first discovered in Michigan in 2002 (Kashian and Witter 2011). Since its introduction, EAB has spread, killing tens of millions of ash trees. Spreading out from the epicentre of the EAB invasion near Detroit, Michigan, ash mortality in southeastern Michigan has reached nearly 100\% (Klooster et al. 2014, 2018); this level of mortality and loss is expected in subsequently invaded areas without intervention. Black ash is largely restricted to wet areas where regeneration has been observed to be less abundant, therefore, it may be particularly susceptible to EAB-induced mortality (Kashian and Witter 2011). The loss or removal of black ash without secure stand regeneration is likely to lead to major shifts in forest structure, composition and site hydrology, with the conversion of these forests to wetlands dominated by shrubs, grasses and sedges (Pailk et al. 2012; Slesak et al. 2014; Telander et al. 2015). Indeed, studies of wetlands depleted of black ash in Min- nesota have indicated a lack of woody species capable of replacing the overstorey and a strong response of herbaceous understorey cover to loss of canopy (Davis et al. 2017; Palik et al. 2021). D'Amato et al. (2018) indicated that it is imperative to identify silvicultural interventions that retain mature seed-producing black ash trees to promote seedling establishment and make recovery or resistance possible following EAB invasion.

Few studies of natural black ash regeneration have been conducted, and these have largely occurred in the boreal forest of northern Quebec (e.g., Tardif et al. 1994; Tardif and Bergeron 1999) or Minnesota (Palik et al. 2012). In mature boreal forest stands dominated by black ash, recruitment is associated with small scale disturbances known as tree by tree replacement (Tardif and Bergeron 1999). Here, the loss of a mature tree creates a gap that releases advance regeneration in the understorey and leads to subsequent recruitment to the canopy. Major disturbances (e.g., fire) are less common (Sims et al. 1990), although fire has been observed in the boreal forest on the upland margins of floodplain habitats (Tardif and Bergeron 1999; Kames et al. 2011). Black ash reproduces both sexually and asexually through the production of stump sprouts. Tardif et al. (1994) found that the major mode of reproduction was determined by fluctuations of the water level, with vegetative reproduction largely occurring on sites most exposed to flooding. Sexual reproduction was more common on sites with less severe or less prolonged flooding. In Minnesota, Palik et al. (2012) studied black ash regeneration in stands exhibiting extensive crown die back. They observed that dieback and regeneration failure were related both to reduction of transpirational water loss and increased soil moisture in these stands and concluded the potential for black ash regeneration to replace the dying canopy trees was low. Loss of the canopy magnifies the change in hydrology and the understorey light regime, making the area suitable for competing species. This suggests that black ash-dominated stands do not typically arise from large scale disturbances.

In the eastern GLSL region of central Ontario, black ash forms associations with a mixture of boreal forest species such as black spruce (Picea mariana (Mill.) BSP) and eastern deciduous forest species such as red maple (Acer rubrum L.). Often black ash occurs in small, localized, pure stands on wet sites or in association with other species on mesic sites (Sims et al. 1990). As such, few studies have considered the regeneration ecology of black ash in this region. Given the different climate and species composition of the GLSL, observations from studies in other forest regions should not be broadly applied by forest managers without first examining regeneration of black ash in situ. In Ontario, the general principles of emulating natural disturbance regimes and matching regeneration to site conditions should be applied. This requires direct knowledge of the dominant disturbance pattern that gives rise to stands dominated by black ash. The objective of this study was to describe patterns of regeneration of black ash in a sample of stands within the GLSL and to determine the relationships between multiple indicators of regeneration success and biotic and abiotic factors. Given that black ash typically dominates on wet, rich soils and has been associated with small-scale disturbance patterns in other forest regions, 
this study focused on the hydrological and nutrient availability aspects of site quality, and measured canopy closure, stand age and diameter distributions to elucidate recent disturbance regimes in these forests.

\section{Methods}

\section{Study area}

This study was conducted in the area surrounding Lake Nipissing near the city of North Bay in central Ontario, Canada (Fig. 1). The area is situated near the northern margin of the GLSL within the Georgian Bay ecoregion (Rowe 1972). According to the most recent Forest Resources Inventory (FRI) for the local management unit, black ash stands comprise a small percentage of the Nipissing forest, with $0.1 \%$ of the land cover having $50 \%$ or greater black ash cover. Black ash primarily occurs in low-lying areas surrounding Lake Nipissing, along riverbanks, along road ditches and in old stream beds. Black ash stands in the area are small, reaching a mean size of approximately eight hectares. Overstorey species associations in the Nipissing Forest, particularly with red maple and eastern white cedar (Thuja occidentalis L.), are similar to those identified elsewhere in the GLSL. Given the similar size and composition of black ash stands in the Nipissing forest compared to black ash stands elsewhere, the sample used in this study provides a good representation of the conditions in which black ash dominates within the Georgian Bay ecoregion of the GLSL.

According to Environment Canada (2017), data from the nearest weather station in North Bay, Ontario, indicate that mean daily temperature is $4.2^{\circ} \mathrm{C}$, mean daily temperature of the coldest (January) and warmest (July) months are $-12.5^{\circ} \mathrm{C}$ and $18.9^{\circ} \mathrm{C}$, respectively. Mean annual rainfall is $802.8 \mathrm{~mm}$, snowfall is $299.6 \mathrm{~mm}$ and total precipitation is $1044.6 \mathrm{~mm}$ (Environment Canada 2017). The majority of the Nipissing Forest is located within the Georgian Bay Ecoregion (5E) on the southern part of the Precambrian shield. The landscape is dominated by bedrock of migmatitic gneisses and felsic igneous rocks covered with varying amounts of till. The area that is not bedrock has glaciofluvial outwash deposits, till deposits and glaciolacustrine deposits of predominantly humoferric podzol soil (Gartner 1980).

\section{Sampling design}

Black ash-dominated sites were selected following a randomized sampling design using the most current version of the FRI available for the Nipissing Forest. Potential study site locations were identified based on the pool of stands (polygons) that satisfied a suite of selection criteria. FRI polygons were identified that had stand age $>30$ years, polygon area $>$ 1 ha, canopy cover $>70 \%$, black ash cover by basal area $>$ $50 \%$, distance from a road $<350 \mathrm{~m}$, and that were completely contained within parcels of crown land or protected areas. Stands considered for plot establishment had to be free of recent large-scale disturbances such as logging. Ultimately, 12 suitable locations provided a good representation of the range of conditions in which black ash dominates across the study area and were selected for sampling (Fig. 1). Using the Geospatial Modeling Environment (Spatial Ecology LLC, Version 7.3.0), an ArcGIS (ESRI, West Redlands, CA, USA) add-on, three random points were created in each of the stands to serve as potential plot centres, and GPS coordinates were extracted for these points. At each selected GPS point within a stand, a $400 \mathrm{~m}^{2}$ circular plot (radius $=11.3 \mathrm{~m}$ ) was established. The plot centre location was identified in the field using a recreational grade Garmin 60 csx GPS unit (Garmin International Inc., Olathe, KS, USA), and this procedure typically yielded a positional accuracy of $\pm 3 \mathrm{~m}$. Within each 400 $\mathrm{m}^{2}$ circular plot, three $2 \mathrm{~m} \times 2 \mathrm{~m}$ square vegetation sub-plots (Fig. 2) were randomly established.

\section{Plot-level data and sample collection}

Three variables related to topography (elevation, slope) and hydrology (topographic wetness index) were calculated for each plot. All variables were derived from the Ontario Integrated Hydrology Digital Elevation Model (DEM) obtained from the OMNRF (https://www.ontario.ca/data/ontariointegrated-hydrology-data), which has a spatial resolution of $30 \mathrm{~m}$, and were calculated using ArcGIS version 10.4. The plot areas were projected as polygons ( $400 \mathrm{~m}^{2}$ circles), and the DEM-derived variables as a raster, in the Universal Transverse Mercator (UTM) projection for Zone $17 \mathrm{~N}$ in the 1983 North American Datum (NAD83). Mean elevation (m) in each plot was calculated using the zonal statistics tool in the spatial analyst extension of ArcGIS. Slope was calculated using the surface tool in the spatial analyst extension and summarized for each plot using the zonal statistics tool. Flow direction and flow accumulation rasters were created from the DEM using the hydrology tools in the spatial analyst extension. These layers were then used to create a Topographic Wetness Index (TWI) raster which was calculated following Bevin (2001) as TWI $=\ln (\mathrm{a} / \tan \mathrm{b})$, where $\mathrm{a}=($ flow accumulation * DEM resolution) and slope is expressed in radians $(\pi / 180)$. Mean TWI was calculated for each plot using the zonal statistics tool.

Two soil samples were taken near the plot centre at a depth of 5-15 cm from the surface. Soil samples were collected from a given plot on a single day during the growing season. The collection date for individual plots differed, spanning from June 30 - Aug. 31, 2016. Gravimetric soil moisture was calculated from fresh and dry weights of each sample (Topp 1993), with samples dried to a constant weight at a temperature of $55^{\circ} \mathrm{C}$. Given the extended period over which soil samples were collected, there was potential for variation in the soil moisture data related to the seasonality of hydrological processes and precipitation events. Neither the Julian day nor 7- or 14-day precipitation prior to sampling had any significant association to the measured soil moisture or the ranking of soil moisture among plots (Springer 2019). Therefore, the soil moisture data were considered to be representative of the spatial variation in moisture availability among stands. Dried soil samples (300 g) were assembled as a composite mixture of the two samples from each plot and sent to the Agriculture and Food Laboratory at the University of Guelph for analysis. Soil $\mathrm{pH}$ was measured using the paste method. Concentrations of soil $\mathrm{K}$ and $\mathrm{Mg}$ were measured on samples extracted using $1.0 \mathrm{~N}$ ammonium acetate solution and determined using an ICP-OES. To measure soil $\mathrm{P}$, samples were extracted using $0.5 \mathrm{M}$ sodium bicarbonate solution and the concentration of $\mathrm{P}$ in the extract was determined colourimetrically using a Seal AA3. For total N (\% by weight), 


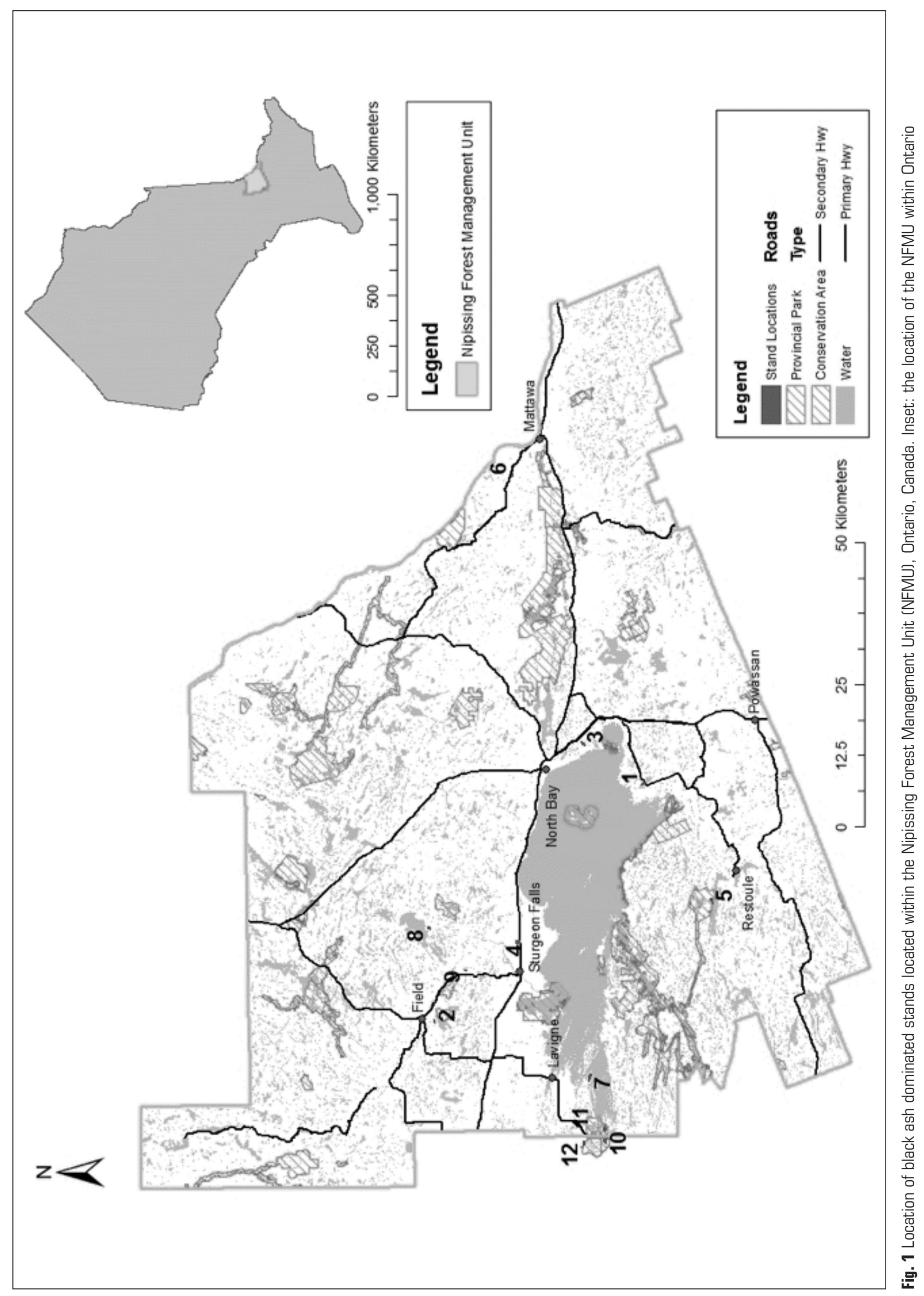




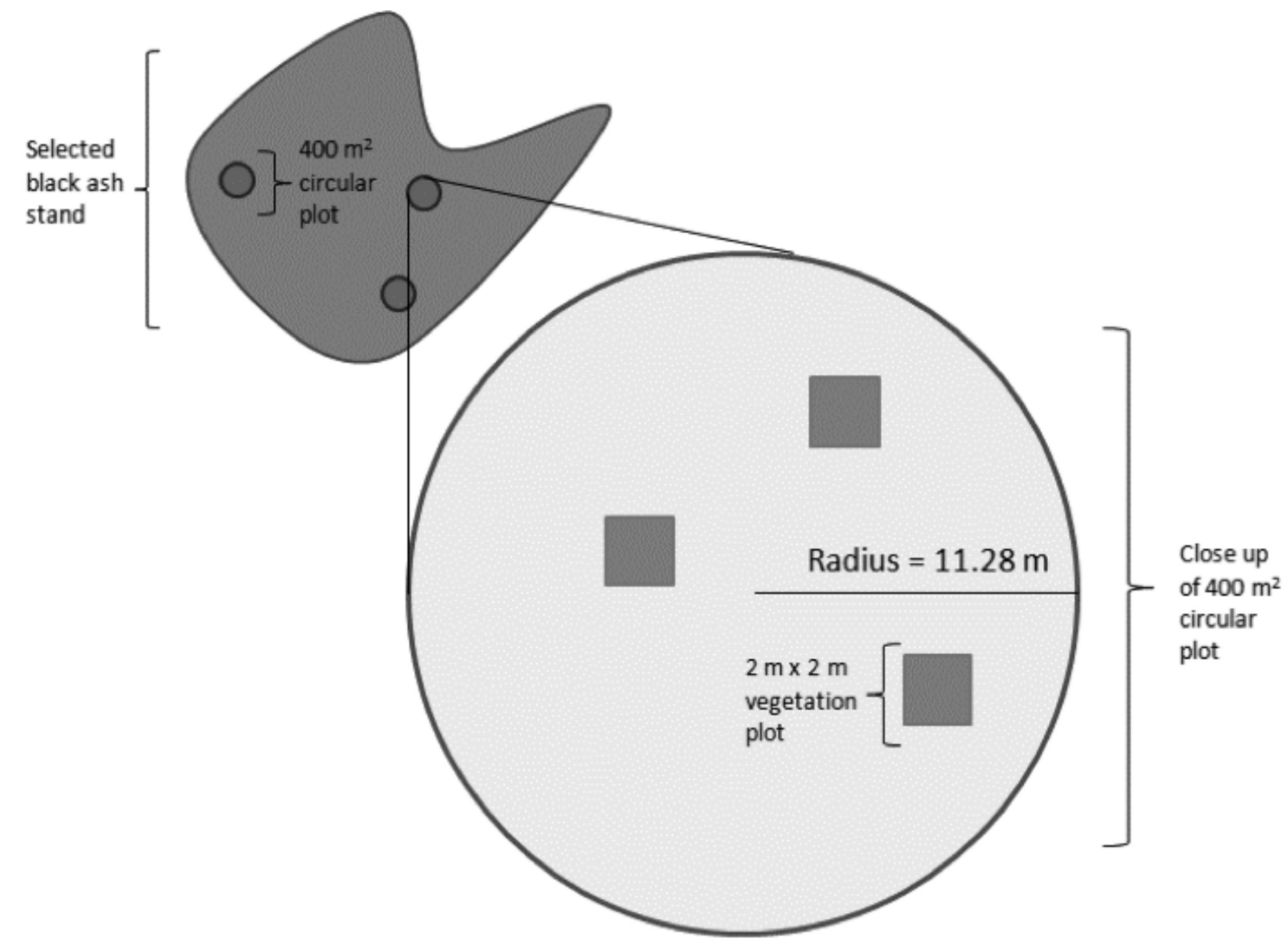

Fig. 2 Sketch of the sample plot design. Black ash stands had three $400 \mathrm{~m}^{2}$ circular plots with locations chosen at random. In each $400 \mathrm{~m}^{2}$ circular plot, three $2 \mathrm{~m} \times 2 \mathrm{~m}$ sub plots were established in random locations

ground or sieved samples were combusted in a sealed system and released nitrogen compounds reduced to $\mathrm{N}_{2}$ gas were measured using a LECO FP428.

Within each $400 \mathrm{~m}^{2}$ plot, all living stems $\geq 10 \mathrm{~cm}$ diameter at breast height $(1.3 \mathrm{~m})$ were identified to the species level and their DBH measured. Measurements of canopy closure were taken by two observers facing each cardinal direction from the plot centre with a handheld convex spherical densiometer, and ultimately expressed as a mean for the plot (Model A, Forestry Suppliers, Jackson, MS, USA). Increment cores (5-mm diameter) were collected to estimate the age of the main canopy layer in each stand. A random sample of five dominant or co-dominant trees in each plot (15 per stand) were cored at basal height $(30 \mathrm{~cm})$ using an increment borer (Haglöf Sweden AB, Långsele, Sweden). Cores were mounted and sanded following standard techniques (Stokes and Smiley 1968; Speer 2010) and rings counted under a binocular dissecting microscope (Olympus SZ61, Center Valley, PA, USA). Age was estimated from these ring counts, given that black ash does not produce false rings (Palik et al. 2001). For samples in which the core did not strike the pith directly, the number of missing rings was estimated based on ring curvature to better estimate tree age (Applequist 1958; Speer 2010).

Within each $400 \mathrm{~m}^{2}$ plot, three $4 \mathrm{~m}^{2}$ vegetation sub-plots were established in random locations. All understorey vege- tation species (excluding mosses and lichens) in the sub-plots were identified and assigned a cover value based on a standard scale: $1=0-5 \%, 2=5 \%-25 \%, 3=25 \%-50 \%, 4=50 \%$ - 75\%, 5=75\% - 95\%, and 6 = 95\% -100\% cover (Daubenmire 1968). Vegetation with height less than 2-m was considered part of the understorey cover. Cover values were assigned on different days for each stand, and observations spanned the growing season from June 30 - August 31, 2016. The same two observers assessed cover for all the plots to maintain consistency. Mean cover was calculated from all observations in the vegetation plots within a stand. Species richness was determined at the stand level from the cumulative total species observed in the three $400 \mathrm{~m}^{2}$ plots. Shannon's diversity index $(\mathrm{H})$ and Pielou's evenness index $(\mathrm{J})$ were calculated from the stand level cover values (McCune et al. 2002). Samples were identified following Britton and Brown (1970), Newcomb (1977), and Gleason and Cronquist (1991). Voucher specimens of all species were deposited in the Nipissing University herbarium. Understorey vegetation cover data were reported and analyzed in Springer (2019).

In each sub-plot, all stems of black ash $<10 \mathrm{~cm} \mathrm{DBH}$ were considered as part of the regeneration layer (Palik et al. 2012; Klopcic et al. 2015). Stems of regeneration were classified into four categories, depending on size. A germinant was assumed to be 1-2 years in age and defined as having a basal diameter 
$<0.5 \mathrm{~cm}$. Seedlings were defined as having a basal diameter $>$ $0.5 \mathrm{~cm}$ and a height $<1.3 \mathrm{~m}$. Saplings were defined as having a height $>1.3 \mathrm{~m}$ and a diameter $<10.0 \mathrm{~cm}$. Sprouts were defined as all stems of regeneration clearly originating from a pre-existing root system (i.e., attached to a pre-existing stump or a stem). All stems of black ash regeneration were counted in each sub-plot, and their basal diameter and height measured. Given the large number of germinants in some sub-plots, a sample of approximately $10 \%$ of the total number of germinants was measured to calculate an average height and diameter for the sub-plot. For tall stems (e.g., saplings and sprouts) that could not be measured with a tape, a vertex sonic clinometer and transponder (Haglöf Sweden $A B$, Långsele, Sweden) were used to determine the stem height to the nearest $0.1 \mathrm{~m}$. Within each subplot, a maximum of three samples from each black ash regeneration type (germinants were excluded due to their small size) were collected for aging. This gave a total of nine samples per subplot, $27 \mathrm{sam}$ ples per plot, and 81 samples per stand. In some cases, there were fewer samples due to a lack of seedlings, saplings or sprouts. Stems were cut at the base and a cross-section taken for all samples $<5 \mathrm{~cm}$ in diameter. In cases where stems were large (> $5 \mathrm{~cm}$ basal diameter) a basal increment core was extracted instead of cutting a basal cross-section. Cross-sections or cores were ring-counted to the pith or to the last complete ring under a binocular dissecting microscope. Pith location estimation based on ring curvature was performed on cores that missed the pith, in order to better estimate tree age (Applequist 1958; Speer 2010). Basal diameter and height were recorded for each of the regeneration samples used to determine age.

\section{Data analysis}

Data and samples were collected to generate variables to represent black ash stands at three different nested scales. To describe regeneration patterns among stands (variable area depending on the size of the FRI polygon), data were collected at the plot $\left(400 \mathrm{~m}^{2}\right)$ and the subplot $\left(4 \mathrm{~m}^{2}\right)$ levels. All variables were ultimately expressed at the stand level $(n=12)$. Therefore, all derived variables were summarized for the full set of sub-plots (e.g. regeneration variables $n=9$ ) or plots (e.g. environmental variables $n=3$ ) by calculating the mean of a particular variable in a given stand. Stand-level data were entered into variable by stand matrices, one that included all environmental variables, and one that included all black ash regeneration variables.

Principal component analysis (PCA) was used to analyze the environmental variable matrix. PCA is appropriate for summarizing linear relationships among variables in data sets that have relatively few zero values (McCune et al. 2002; Kenkel 2006; Kent 2011; Legendre and Legendre 2012), and is the most common ordination technique used to analyze environmental data as a form of direct gradient analysis (Kent 2011). The environmental PCA ordination matrix was composed of ten variables, describing the environment (canopy closure, soil moisture, $\mathrm{pH}, \mathrm{P}, \mathrm{K}, \mathrm{Mg}, \mathrm{N}$, elevation, TWI, and slope), in the 12 stands studied. The selected crossproducts matrix was composed of correlation coefficients, thereby standardizing the PCA and eliminating the influence of variables with different scaling (Kenkel et al. 2002). Given that the objective of the analysis was to describe environmen- tal gradients of importance, it was not necessary to employ tests of statistical significance of the extracted components; however, the broken stick scores for components (Legendre and Legendre 2012) were used to identify the useful axes that were interpreted. Joint plots were used to visualize the results of the PCA in two dimensional space for pairs of graphed axes. Ordination diagrams were scaled proportionate to the longest axis (scores plotted as a \% of maximum) to preserve the similarity among points, and joint plot vectors were rescaled as necessary so that they projected within the ordination plots. The explained variance for each component extracted in the PCA was examined to assess the usefulness of the ordination (McCune et al. 2002).

After examining the bivariate correlation coefficients (Spearman's rho) and a scatterplot matrix, it became clear that the regeneration variables were largely characterized by linear relationships. Furthermore, the number of zero values in the regeneration data matrix was also assessed, which was $20 / 180=11.1 \%$. The correlation analysis and lack of frequent zero elements in the data provided strong evidence that PCA would be the most appropriate ordination technique to analyze the regeneration data. The ordination matrix was composed of 23 variables; means of the density, dominance and frequency (per unit area), as well as diameter, height, and age (age of germinants excluded) of each type of regeneration (seedlings, saplings, sprouts and germinants), represented in each of the twelve stands. The PCA of regeneration variables followed the same conventions as described and justified above for the environmental ordination. All ordinations were completed using PC-ORD software version 4.2 (MJM Software $\mathrm{Co}$, Gleneden Beach, OR., USA). In order to explore the association between regeneration components and stand/environment variables, the direct bivariate correlation coefficients were examined. Given that some of the variables had non-normal distributions, only nonparametric correlation coefficients (Spearman's rho) were considered. Correlation analyses were performed in SPSS version 22 (IBM Corporation, Armonk, NY, U.S.A.).

\section{Results}

\section{Environmental factors}

There was considerable variation of the means of most of the measured environmental variables across the stands (Table 1). Soil $\mathrm{pH}$ was acidic in all stands, with the majority of means falling between 5.0 - 5.4. Plant-available soil nutrients varied widely among stands. In the case of $\mathrm{P}$, values largely fell between $3-9 \mathrm{mg} \mathrm{L}^{-1}$, with low variation in any given stand. The availability of both $\mathrm{K}$ and $\mathrm{Mg}$ followed a similar pattern and generally were grouped into high and low value stands (Table 1). Total soil $\mathrm{N}$ ranged between 0.17 and $0.41 \%$ across the majority of stands. Relatively high N levels (> 1.00\%) were observed in stands 1 and 5 , and the lowest mean value was observed in stand $4(0.06 \%)$. In general, stands were wet, with mean soil moisture that varied from $17-86 \%$. Most stands had soil moisture near the lower end of this range (e.g., < $40 \%$ ), with the exception of stands 1,5 and 6 , which ranged from $64-86 \%$. The TWI values were similar in most stands (Table 1), with the notable exceptions of stands 1 and 11 , which had much higher values, indicating that these were areas where water collects substantially on the landscape. Slope and elevation data suggested that most stands were low 


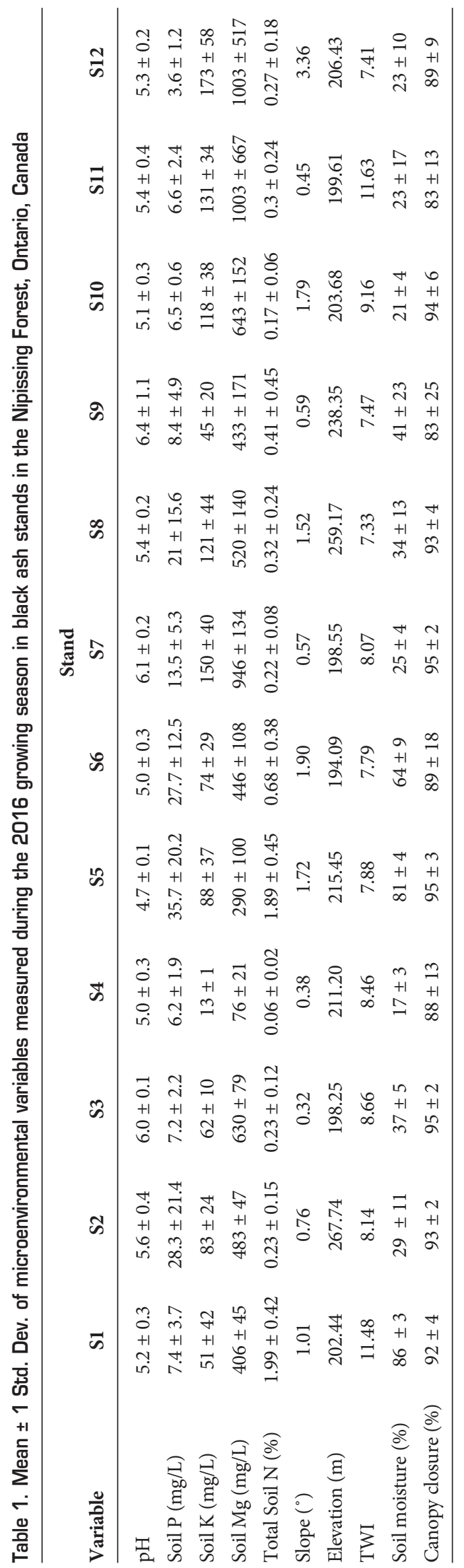

and relatively flat (Table 1), although there were a few stands with mean slopes $>1$ and/or mean elevation greater than 215 $\mathrm{m}$. Mean canopy closure was above $80 \%$ in all stands, indicating that these stands were free of recent intensive disturbance. However, several stands had high variation around mean canopy closure, suggesting that there were canopy gaps in stands 4, 6, 9 and 11 (Table 1).

The PCA of the environmental variables produced three useful axes that explained $33.5 \%, 23.1 \%$ and $20.3 \%$ of the variance, respectively (Fig. 3). The majority of stands formed a group on the negative side of axis one, whereas only stands 1,5 and 6 were on the positive side. Soil moisture and soil $\mathrm{P}$ and $\mathrm{N}$ had strong positive associations on axis one, whereas $\mathrm{pH}$ had a strong negative association. Axis one captured a difference in soil types, with very moist, acidic soils that contained high levels of total $\mathrm{N}$ isolated at the positive end. This interpretation was further supported by the relatively high acidity, total $\mathrm{N}$ and soil moisture in stands 1, 5 and 6 (Table $1)$, suggesting the three stands had impeded drainage and some build-up of organic material. Stand scores along axis two were distributed along a continuum (Fig. 3). Magnesium, $\mathrm{K}$ and slope had positive associations on axis two while elevation and $\mathrm{pH}$ had negative associations. The stands appeared to be arranged in ascending order on axis two according to nutrient levels, specifically the base cations. Axis three was related to TWI (negative) and had weaker associations to P and elevation (positive). Stands at the positive end of axis three were sites that generally shed water and also had higher levels of P. Orthogonality between all axis pairs was 100\% (r $=0.00$ ), indicating no relationship between any of the three interpreted axes.

\section{Vegetation}

Based on the basal area of all trees in the plots, the 12 stands were dominated by black ash (Table 2). Tree species composition among stands varied from pure black ash to mixtures with eastern white cedar, red maple, black spruce or balsam fir (Abies balsamea (L.) Mill). Basal area values were typically around $30 \mathrm{~m}^{2} /$ ha with a range from $38.3 \mathrm{~m}^{2} /$ ha to $22.6 \mathrm{~m}^{2} / \mathrm{ha}$ (Table 2). Most stands exhibited a reverse-J diameter distribution, suggesting that the age structure could be multicohort (Fig. 4). The mean DBH of all trees $\geq 10 \mathrm{~cm} \mathrm{DBH}$ was less than $20 \mathrm{~cm}$ in each stand, with the exception of stand 10 where it was $24.5 \mathrm{~cm}$. The lowest mean DBH was $15.3 \mathrm{~cm}$ in stand 3. Most of the stands had mean stem ages $>75$ years and contained veteran trees ( $>100$ years old), with the only exceptions being stands 7 and 12, at 59 and 64 years-of-age, respectively. The oldest stand (stand 6) had a mean stem age of 116 years and contained the oldest tree sampled in the study at 167 years.

Ninety taxa of understorey vegetation were recorded in the vegetation sub-plots across the 12 stands. Black ash was the most abundant and frequent understorey species in all stands. Despite some of these differences among the stands, the overall mean $\mathrm{H}$ value was 2.74 with a standard deviation of 0.21 , whereas the mean J value was 0.79 with a standard deviation of 0.06 , both indicating that there was little variation in the diversity indicator values in the understorey of these black ash swamps, and that in general these stands are not strongly dominated by any one understorey species (Table 3). 

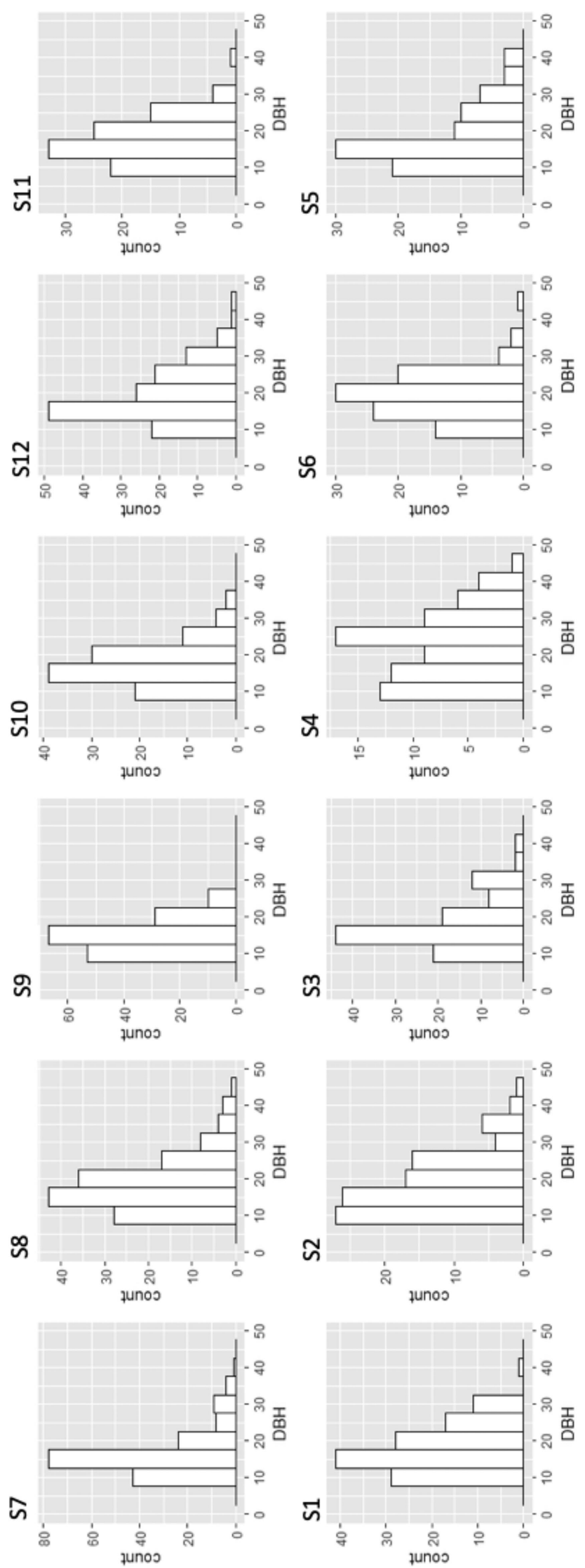

\section{Black ash regeneration}

Regeneration samples (excluding germinants) ranged broadly in age from 1 to 93 years. Seedlings ranged in age from 1-52 years, sprouts from 1- 69 years and saplings from 9 - 93 years (Table 4). These age data indicate that black ash can survive long periods of suppression in the understorey. Density of each type of regeneration varied among stands, with some stands having one dominant type of regeneration and others having a mixture of various types. Germinants were common in all stands, except stands 6 and 9, and were uniform in size across all stands. Seedlings were common in most stands; however they were absent in stands 3,5 , and 11 . There was a low density of saplings in most stands with the exception of stands 9 and 12 ; however, saplings were present in all stands. Sprouts were the dominant type of regeneration in stand 5, were common in stand 12 , and absent from stands 2 and 3. Across the stands, sprouts had a consistent diameter but variable height. Overall, the greatest density of all types of regeneration was found in stand 10 due to a considerable number of germinants. The lowest density of regeneration was observed in stand 6 . Excluding germinants, stand 9 had the highest density of regeneration and stand 3 the lowest.

The PCA of the regeneration variables produced four useful axes that explained $36.5 \%$, $18.3 \%, 13.0 \%$ and $11.8 \%$ of the variance. Stand scores on axis one were distributed continuously along the gradient represented by this axis (Fig. 5). Seedling density, diameter, height, dominance, frequency and age, as well as germinant diameter and height, had negative associations on axis one. Sapling diameter, height, dominance, and frequency, as well as sprout frequency had positive associations. The pattern of scores on axis one suggests a gradient of the abundance of sexual (non-sprout) sources of regeneration, with stands having abundant seedling regeneration on the negative end and those with a well-developed sapling layer at the positive end. Axis two reflected a gradient in which sprout density, diameter, height, frequency and age all had negative associations on the axis, while germinant density and dominance were the only strong positive associations. This suggested that axis two captured a gradient of sprout abundance as a source of regeneration in the stands. Stand scores on axis three were continuously distributed along the gradient (Fig. 5). Strong positive associations on the axis included germinant density and frequency, while the sole notable negative association was sapling dominance. Axis four was positively correlated to seedling diameter, height and age. Orthogonally between axis pairs, 1,2,3 and 4 was $100 \%(r=0.00)$, indicating no relation between the axes. 


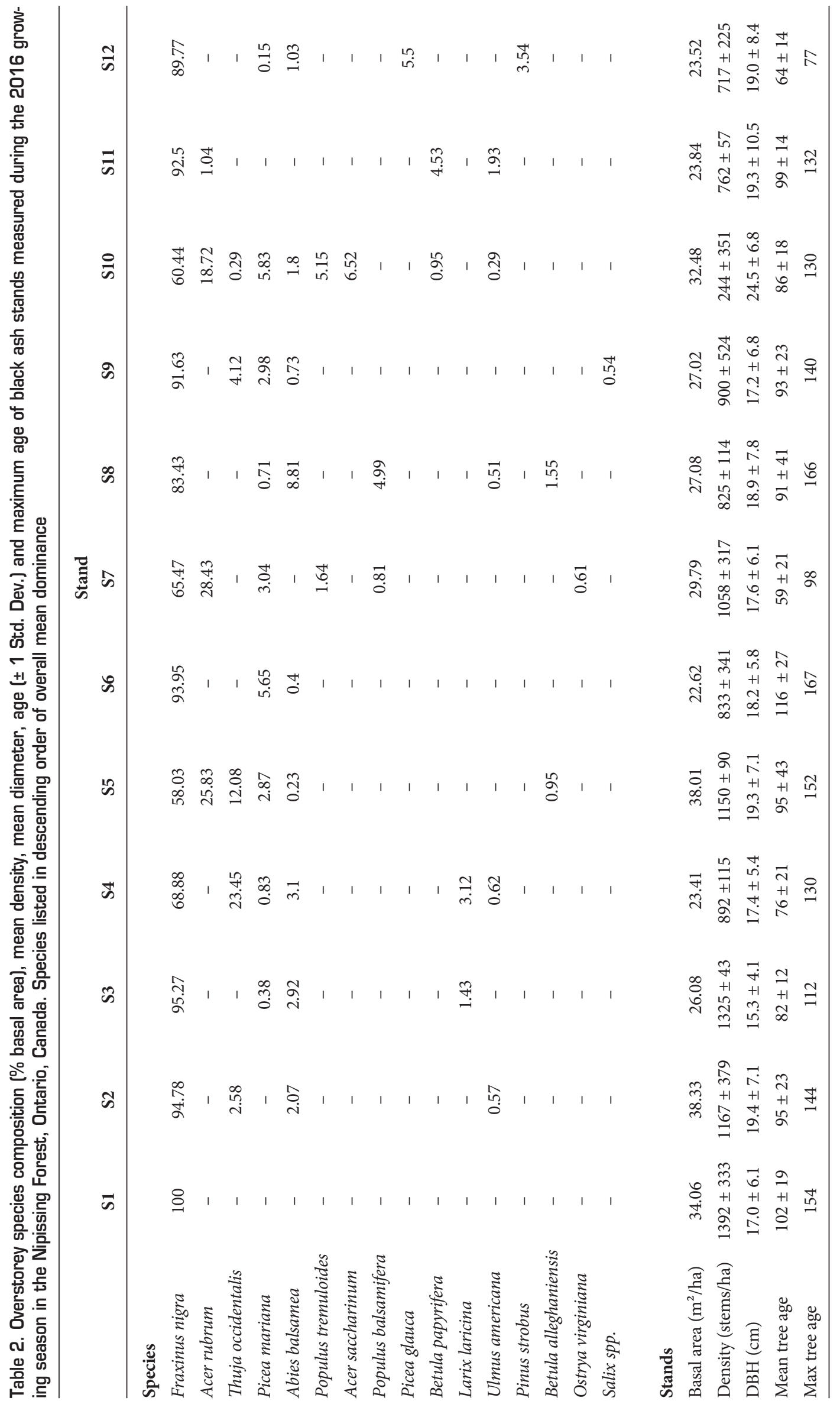



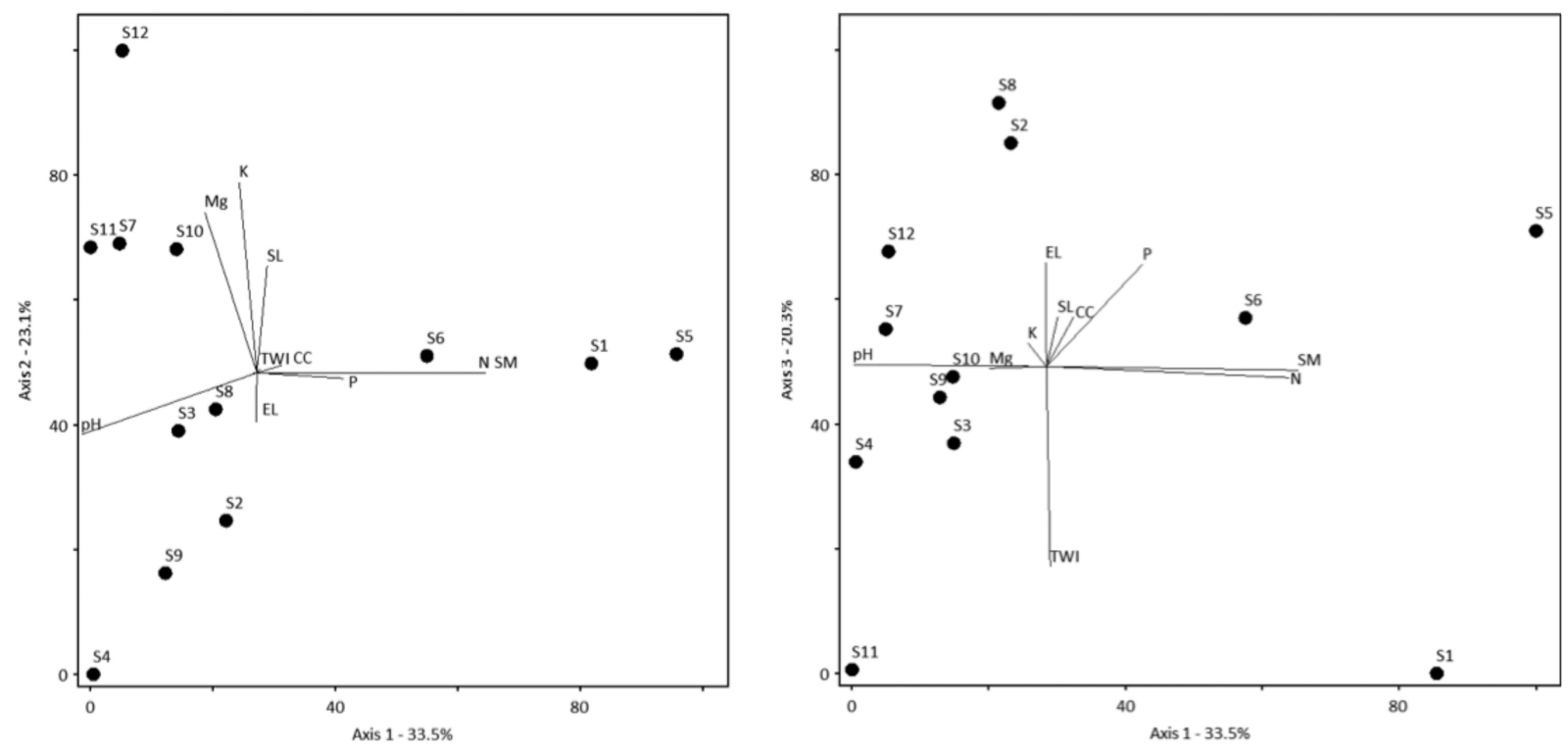

Fig. 4 Joint plot of the PCA of the environmental data showing stand scores and variable vectors projected on the ordination space defined by Axes 1, 2 and 3. Source data were collected in the 2016 growing season in black ash stands in the Nipissing Forest, Ontario, Canada. Principal components were based on the correlation matrix

\section{Correlation analyses}

To gain insights into different aspects of regeneration, bivariate correlations were calculated between regeneration and environmental and stand variables (Table 5). Black ash cover in the understorey had a positive significant relationship to the standard deviation of canopy closure. Notably, the association between percent cover of black ash in the understorey and mean canopy closure was not significant. Seedling height was also positively correlated to the standard deviation of canopy closure. These correlations suggest that it is variability in canopy closure that is driving black ash cover in the regeneration layer. Germinant diameter and dominance had significant relationships to elevation (positive) and soil moisture (negative), respectively. These correlations indicate that soil saturation may be a barrier to the establishment of newly germinated seedlings. Sapling diameter and height were both positively correlated to soil $\mathrm{P}$, while sapling age was negatively correlated to soil $\mathrm{Mg}$, supporting the idea that black ash does better on nutrient rich sites. Sprout diameter, height and age had significant negative correlations with $\mathrm{pH}$, TWI, and $\mathrm{Mg}$, while sprout height was also positively correlated to total soil $\mathrm{N}$ (Table 5). Collectively, these correlations point to the importance of saturated conditions as a driver of sprout production in black ash.

\section{Discussion}

Stands dominated by black ash were organized along three major environmental gradients based primarily on soil characteristics and hydrology. Wet mineral soils, with impeded drainage in low lying areas, were the prevalent habitat for mature black ash, and these were the stands where the species dominated most strongly in the overstorey. As a result of impeded drainage, high levels of total $\mathrm{N}$ were also measured in these stands. This $\mathrm{N}$ was likely associated with organic matter that accumulated in saturated sites, where high water levels impede or slow decomposition. Mature black ash trees are well-adapted to survive in such wet conditions, and can survive flooding for several weeks (Kozlowski 1984; Kurmis and Kim 1989; Sims et al. 1990). Shallow root systems, hypertrophied lenticels, adventitious roots, and rapid stomatal closure are some of the adaptations that allow mature black ash trees to survive flooding when other species cannot (Kozlowski 1984; Benedict and David 2003; Ward et al. 2006). These wet, nutrient rich conditions represent habitat in which mature black ash are able to dominate in the GLSL region. Stands that are better drained tend to be more diverse in overstorey species, with less dominance of black ash in the canopy (Looney et al. 2018). In other regions of Ontario, Quebec, Minnesota, Michigan, and Maine, black ash has also been associated with wet acidic soils and low-lying topography (Barnes 1976; Ward et al. 2006; OMNRF 2015; Costanza et al. 2017).

Black ash cover in the understorey varied in response to variability of canopy closure and mean stand age measured in our study, suggesting a response to light, as lower canopy closure in older stands can be an indication that the stand is undergoing gap dynamics (Yamamoto 2000). In our study, this pattern was evident in the higher standard deviation of canopy closure in older stands rather than a clear difference in mean canopy closure among stands, suggesting the formation of gaps rather than overall effects on the canopy such as declining leaf area in the stand. Palik et al. (2012) found that shrubs such as speckled alder (Alnus incana (L.) Moench) and beaked hazel (Corylus cornuta Marsh.) have the greatest potential to take over black ash stands in the event of canopy dieback or logging, which would increase light availability 
and reduce competition. However, in the stands studied here, we found no negative correlation between black ash cover and cover of understorey shrub species that would suggest strong competition for black ash at the present time (Springer 2019). The presence of these species at the current time may be of concern if canopy closure is dramatically reduced by a significant disturbance (such as EAB invasion) in the future.

Sources of black ash regeneration were found in every stand, however, these varied broadly in density and type. The PCA of regeneration variables separated stands primarily based on the dominant type of regeneration present in the stand. Seedling and germinant dominance and size displayed a similar pattern on the ordination (negative correlation to axis one), whereas sapling (positive correlation to axis one) and sprout (negative correlation to axis two) dominance and size each had a different trend on the ordination joint plots. The shift from early phase regeneration (germinants and seedlings) to later phase regeneration (saplings) along axis one of the PCA was not significantly related to any change in environment measured, although in general there was higher canopy closure and soil $\mathrm{P}$, along with a lower $\mathrm{pH}$ in stands with more developed sapling regeneration. It was hypothesized that this regeneration pattern represents the trajectory of succession to black ash dominated stands that are experiencing a disturbance regime characterized by single tree gap dynamics. In support of this hypothesis, the ground cover of black ash (germinants plus seedlings) and seedling height were both positively correlated to the standard deviation of canopy closure, indicating that in stands with gaps of low canopy closure there is more cover of early phase regeneration. As the regeneration develops into the sapling layer, there is a positive correlation of sapling diameter and height to soil P. This suggests better performance of saplings on nutrient rich sites, which is expected for black ash as a species that dominates in nutrient-rich hardwood swamps (OMNRF 2015). Sprouts were correlated to $\mathrm{N}$ (positive) and $\mathrm{pH}$ (negative), suggesting that more sprouts were in locations that were likely to be permanently saturated, which would limit decomposition and result in high pools of total $\mathrm{N}$ (likely from organic sources) and lower $\mathrm{pH}$. Tardif and Bergeron (1999) found that in the boreal forest of Quebec, sprouting was more prevalent on sites exposed to prolonged flooding.

Four stands had relatively low germinant densities, possibly caused by high water levels or low light levels. Soil moisture is the most immediate factor affecting survival of germinated seeds. Tardif and Bergeron (1999) found that periods lacking prolonged or intense flooding allowed for greater survival of black ash seedlings on boreal floodplains. Our observations demonstrated a significant negative correlation between germinant dominance and soil moisture suggesting that higher soil moisture on these sites reduces the cover of germinants. However excessively dry conditions can cause the roots of young black ash to dry out and competing vegetation to establish (Tardif et al. 1994).

Black ash understorey cover was positively correlated to the standard deviation of canopy closure; however, our sample had a limited range of canopy closure values (plot-level values ranged from 60 to $98 \%$ ). Therefore, the ideal canopy closure for germinant and seedling development could not be specifically evaluated from the data collected. Various characterizations of black ash shade tolerance have been reported, 


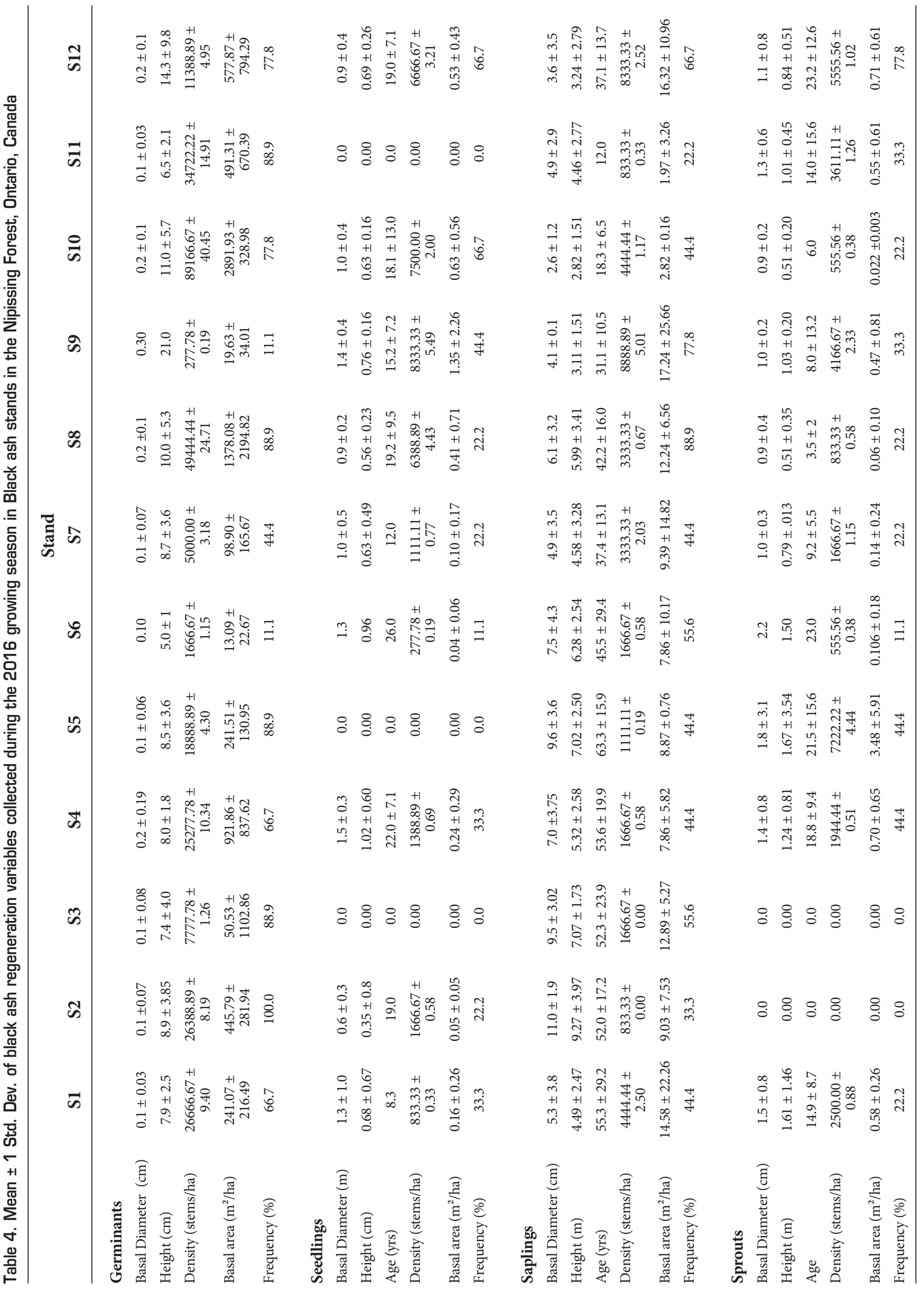



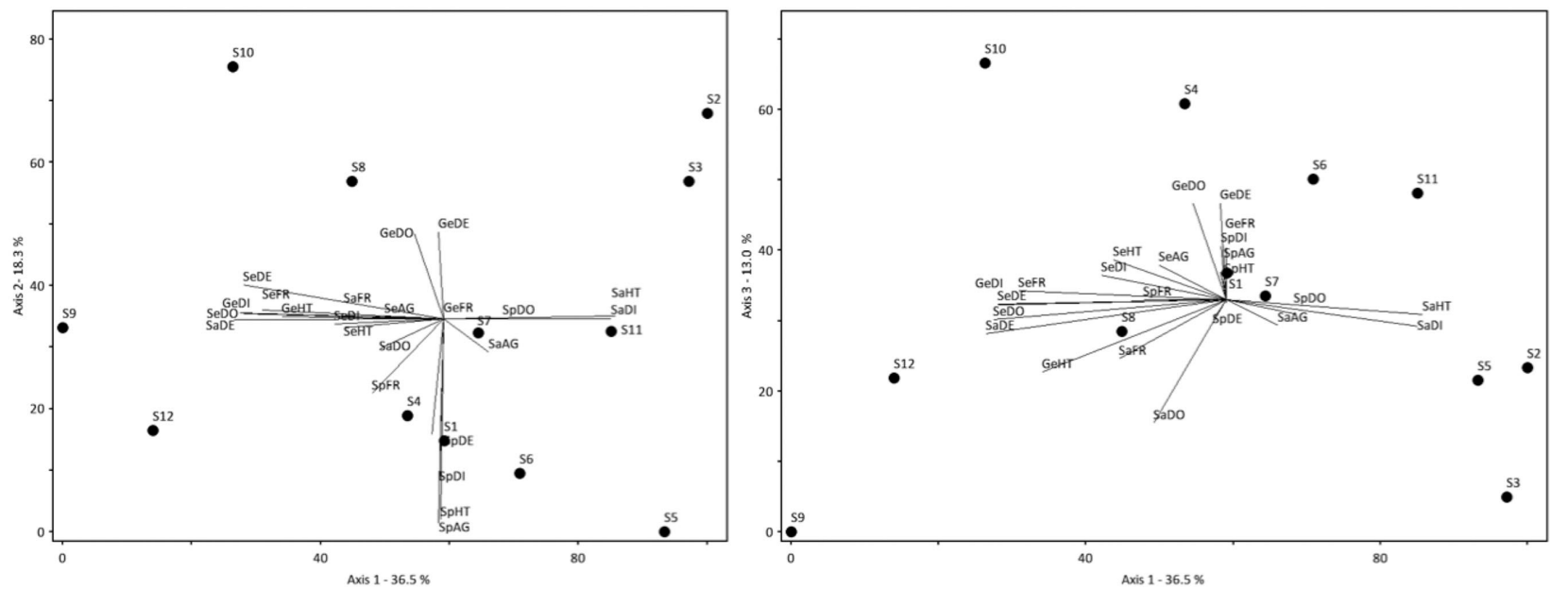

Fig. 5 Joint plot of the PCA of the environmental data showing stand scores and variable vectors projected on the ordination space defined by Axes 1, 2 and 3. Source data were collected in the 2016 growing season in black ash stands in the Nipissing Forest, Ontario, Canada. Principal components were based on the correlation matrix

from shade intolerant to very shade tolerant. Several researchers have suggested that the tolerance of black ash decreases with age (Erdmann et al. 1987; OMNRF 2015). Niinemets and Valladares (2006) developed a 5-unit scale (1 $=$ most, 5 = least light requirements) and classified black ash as moderately shade tolerant bordering on tolerant (2.96) comparable to other shade tolerant species such as eastern white cedar (3.45) and sugar maple (Acer saccharum) (4.76). Age data collected by Tardif and Bergeron (1999) and Townshend (2012), as well as the extensive collection and aging of regenerating stems in this study have all indicated that black ash can reach a substantial age below the canopy. In this study, mean seedling age across all stands was 18 years, maximum age was 52 years, and mean sapling age was 40 years, with a maximum age of 93 years. Such age values have only been described in one other study (Tardif and Bergeron 1999), and clearly indicate that black ash is shade tolerant and can survive long-term suppression in the understorey.

Stands with the highest density of seed-established regeneration were characterized by a water table just below the soil surface. It is likely that early season flooding prevents less saturation tolerant plant species from competing with young black ash regeneration, leading to the establishment of black ash-dominated communities, which has been noted in other regions (Costanza et al. 2017). The conditions outlined above describe what could be considered the core habitat of black ash, as described in the centrifugal organizational model of forest composition (Keddy and MacLellan 1990). The core habitat for black ash can be visualized as the conflux of the environmental gradients centered where each factor best supports black ash. Our results point to this habitat being characterized by high soil moisture with seasonal flooding, high total $\mathrm{N}$, high available $\mathrm{P}, \mathrm{Mg}$ and $\mathrm{K}$, and a canopy with gaps, with the overstorey and understorey dominated by black ash. Black ash can still exist in peripheral habitats outside the optimal conditions, where it is less dominant, mixing with other species such as red maple or American elm (Ulmus americana L.). Some of our stands (2, 3, 5, and 11) are examples of peripheral habitats, as indicated by lower black ash cover in both the overstory and understorey. Sprouting can be an indication that the stand is changing, moving from core habitat to a more stressful peripheral habitat. When sprouting occurs throughout a stand, it can indicate stress caused by sub-optimal environmental conditions, which often also limit the success of seed germination and growth of regeneration from sexual reproduction. In stands that had greater numbers of saplings and sprouts with few to no seedlings or germinants, pooling water during the summer months and/or indirect evidence of past flooding (e.g., high water lines on tree stems and hypertrophied lenticels) was observed. In flood prone areas, the larger root area of saplings and that of the parent root system of individual of sprouts are better able to survive stressful conditions than seedlings (Tardif et al. 1994; Costanza et al. 2017). In these situations, sprouting is a mechanism of the persistence niche, as described by Bond and Midgley (2001), allowing for the continued survival of black ash individuals in a stressful environment.

Based on the evidence collected in this study, black ashdominated stands in the central Ontario portion of the GLSL have been self-replacing, with all stands sampled exhibiting some type of regeneration and recruitment, including a layer of advance regeneration (saplings). Stand diameter distributions generally showed a reverse-J curve diameter distribution, which suggests that several phases of recruitment have occurred in the past (Oliver and Larson 1990). Although our sample of trees for age determination was small (fifteen trees per stand), we consistently observed a broad range of ages in the dominant/co-dominant canopy within single stands, with standard deviations of tree age ranging from 12 to 41 years. Furthermore, trees of substantial age were detected that had experienced long periods of suppression occupying 


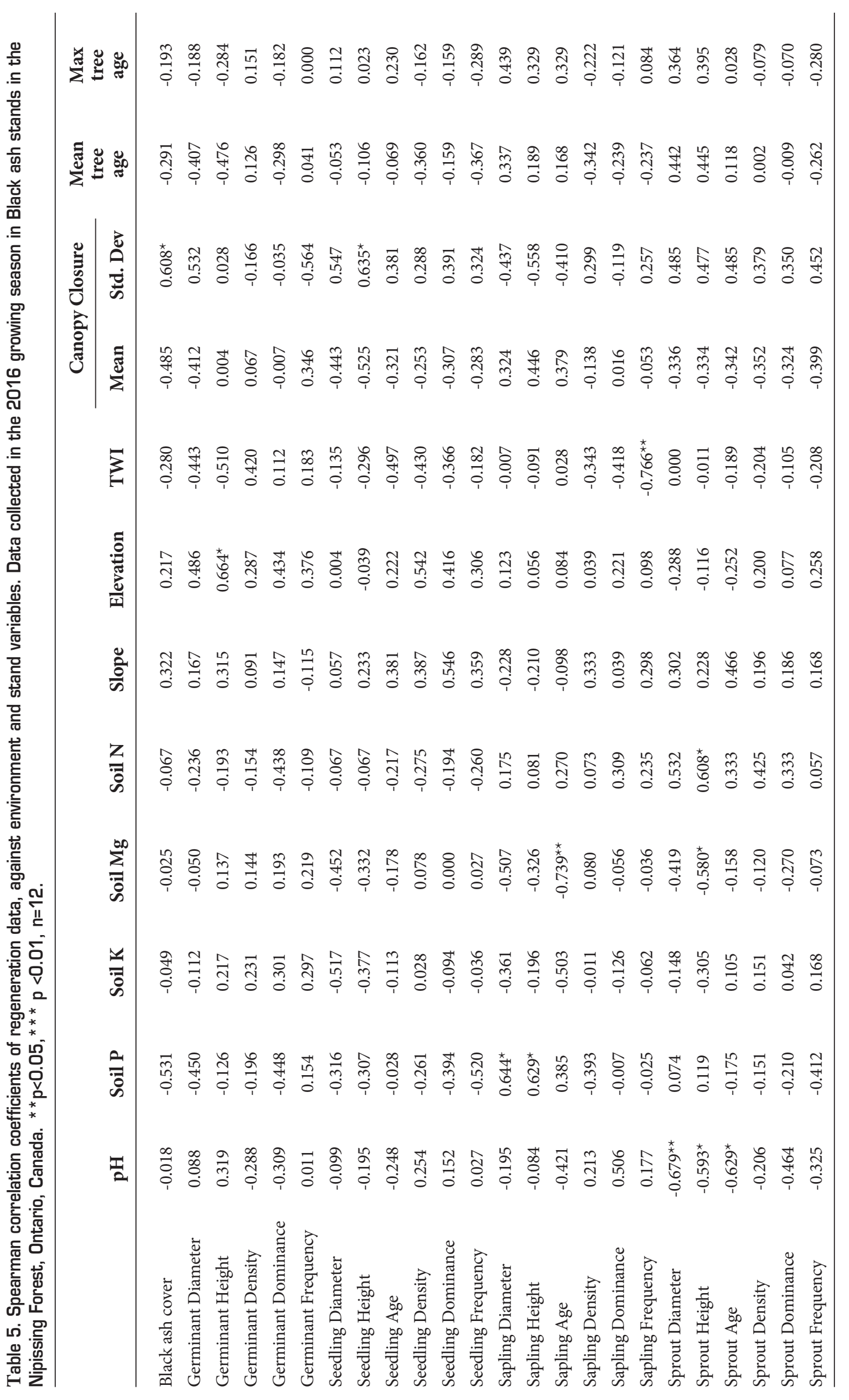


lower crown positions. Collectively, these indicators are interpreted as evidence that black ash stands in this region are multi-cohort in nature. Furthermore, regeneration in these stands was abundant, with the average density of germinants, seedlings and saplings considerably larger than that observed by Palik et al. (2012) in Minnesota, and similar to that observed by Tardif et al. (1994) and Tardif and Bergeron (1999) in the boreal forest of Quebec.

In Ontario, the Crown Forest Sustainability Act of 1994 (https://www.ontario.ca/laws/statute/94c25) requires that silvicultural practices must emulate natural disturbances wherever possible to regenerate forests managed for production. Black ash regeneration success was observed in stands with high variation in canopy closure, an age/diameter distribution that appeared to be multi-cohort, and trees in lower crown positions, as well saplings in the understory of considerable age. Thus, the disturbance regime affecting stands where black ash is regenerating best is characterized by the formation of gaps that are likely occupied by seedlings or saplings capable of persisting for long periods of time in the understorey. Collectively, this leads us to the recommendation of single tree selection as the best method for emulating the natural disturbances that occur in these stands. The current guidelines for lowland hardwood stands (Sims et al. 1990; OMNRF 1998, 2015), which would include black ash stands, suggest the use of partial harvest methods, particularly the uniform shelterwood system, to retain 70\% canopy closure in order to reduce changes to hydrology. Our suggestion of a single tree selection silvicultural system to manage black ash in the GLSL, would create targeted variation in canopy openness and would minimize the impacts on the hydrological regime. Major alterations to the hydrologic regime could result in the conversion of these habitats to domination by competing species such as sedges (e.g., Carex crinita Lam., C. communis L.H. Bailey) and shrubs (e.g., speckled alder), which attained relatively high levels of cover on the stands studied (Springer 2019). Group selection is a second option, which based on our observations, would be beneficial in locations along stand edges or on microsites where pockets of abundant regeneration are present, including larger early stage regeneration such as seedlings and small saplings. Slesak et al. (2014) indicated that group selection (0.04 ha gaps) had low risk of vegetation shifts and ecosystem alteration, while clear cutting resulted in increased water levels and a shift to more water-tolerant wetland species. Given that the natural disturbance regime as inferred from our data suggests that black ash regeneration resembles the tree by tree replacement described by Tardif and Bergeron (1999), we anticipate the impending invasion of $E A B$ in these forests will lead to significant changes in their composition and structure.

\section{Acknowledgments}

This work was supported by Nipissing University and the Ontario Graduate Scholarships. Thanks to Peter Nosko, Jacques Tardif and two anonymous reviewers for reviewing a previous draft of this paper. We would also like to express gratitude to Emiley Watson, Ben Coyle, William Humphrey, Kyle Vincent, Tegan McWhirter, Rebecca Wiley and Oriana Pokorny for their help with sampling and sample processing. We were also pleased to receive assistance and support from various individuals at Ontario Parks, The City of North Bay and the Municipality of West Nipissing when locating sample plots on lands under their care.

\section{References}

Applequist, M.B. 1958. A simple pith locator for use with off-center increment cores. J. Forest. 56(2):141.

Barnes, B.V. 1976. Succession in deciduous swamp communities of southeastern Michigan formerly dominated by American elm. Can. J. Bot. 54: 19-24.

Benedict, L. and R. David. 2003. Propagation protocol for black ash (Fraxinus nigra Marsh.). Native Plants Journal 4(2): 100-103.

Benedict, M.A. and L.E. Frelich. 2008. Site factors affecting black ash ring growth in northern Minnesota. Forest Ecol. Manage. 255(8): 3489-3493.

Bevin, K.J. 2001. Rainfall-Runoff Modelling. John Wiley and Sons, West Sussex, UK.

Bond, W. J. and J.J. Midgley. 2001. Ecology of sprouting in woody plants: The persistence niche. Trends in Ecology and Evolution 16(1): 45-51.

Britton, N. L. and A. Brown. 1970. An Illustrated Flora of the Northern United States and Canada. Three volumes, 2nd ed. Dover Publications, New York.

Costanza, K.K., W.H. Livingston, D.M. Kashian, R.A. Slesak, J.C. Tardif, J.P. Dech, A.K. Diamond, J.J. Daigle, D.J. Ranco, J.N. Siegert, L. Benedict, S.R. Fraver and M. Reinikainen. 2017. The precarious state of a cultural keystone species: Tribal and biological assessments of the role and future of black ash. J. Forest. 115(5): 435-446.

D'Amato, A.W., B.J. Palik, R.A. Slesak, G. Edge, C. Matula and D.R. Bronson. 2018. Evaluating adaptive management options for black ash forests in the face of emerald ash borer invasion. Forests 9(6): 348 .

Daubenmire, R. 1968. Plant communities: A textbook of plant synecology. Harper and Row, New York, USA.

Davis, J.C., J.P. Shannon, N.W. Bolton, R.K. Kolka and T.G. Pypker. 2017. Vegetation responses to simulated emerald ash borer infestation in Fraxinus nigra dominated wetlands of Upper Michigan, USA. Can. J. For. Res. 47(3): 319-330.

Environment Canada. 2017. Canadian Climate Normals 19392000. North Bay. Available from: http://climate.weather.gc.ca/ climate_normals/index_e.html/

Erdmann, G.G., T.R. Crow, R.M. Peterson Jr. and C.D. Wilson. 1987. Managing black ash in the Lake States. General Technical Report NC-115. St. Paul, MN: U.S. Dept. of Agriculture, Forest Service, North Central Forest Experiment Station

Gartner, J.F. 1980. North Bay Area (NTS 31L/SW), Districts of Nipissing and Parry Sound; Ontario Geological Survey, Northern Ontario Engineering Geology Terrain Study 101, 19 p. Accompanied by Maps 5041 and 5044, scale: 1:100000.

Gleason, H.A. and A. Cronquist. 1991. Manual of vascular plants of the Northeastern United States and adjacent Canada, New York Botanical Garden, New York.

Kames, S., J.C. Tardif and Y. Bergeron. 2011. Anomalous earlywood vessel lumen area in black ash tree rings as a potential indicator of forest fires. Dendrochronologia 29(2): 109-114.

Kashian, D.M. and J.A. Witter. 2011. Assessing the potential for ash canopy tree replacement via current regeneration following emerald ash borer-caused mortality on southeastern Michigan landscapes. For. Ecol. Manage. 261(3): 480-488.

Keddy, P.A. and P. MacLellan. 1990. Centrifugal organization in forests. Oikos 59(1): 75-84.

Kenkel, N.C. 2006. On selecting an appropriate multivariate analysis. Can. J. Plant Sci. 86(3): 663-676.

Kenkel, N.C., D.A. Derksen, A.G. Thomas and P.R. Watson. 2002. Multivariate analysis in weed science research. Weed Science 50: 281-292. 
Kent, M. 2011. Vegetation Description and Analysis. Wiley-Blackwell. Oxford, UK.

Klooster, W.S., D.A. Herms, K.S. Knight, C.P. Herms, D.G. McCullough, A. Smith and J. Cardina. 2014. Ash (Fraxinus spp.) mortality, regeneration, and seed bank dynamics in mixed hardwood forests following invasion by emerald ash borer (Agrilus planipennis). Biological Invasions 16(4): 859-873.

Klooster, W.S., K.J.K. Gandhi, L.C. Long, K.I. Perry, K.B. Rice and D.A. Herms. 2018. Ecological impacts of emerald ash borer in forests at the epicenter of the invasion in North America. Forests 9: 250-264.

Klopcic, M., T. Simoncic and A. Boncina. 2015. Comparison of regeneration and recruitment of shade-tolerant and light-demanding species in mixed uneven-aged forests: Experiences from the Dinaric region. Forestry 88: 552-563.

Kozlowski, T.T. 1984. Plant responses to flooding of soil. BioScience 34(3): 162-167.

Kurmis, V. and J.H. Kim. 1989. Black ash stand composition and structure in Carlton County, Minnesota. University of Minnesota Staff Paper Series Number 69.

Lee, R. 2004. COSEWIC Status report on flooded jelly skin (Leptogium rivulare) in Canada. COSEWIC. 30 pp.

Legendre, P. and L.F. Legendre. 2012. Numerical Ecology. Elsevier, Amsterdam

Looney, C.E., A.W. D'Amato, S. Fraver, B.J. Palik and L.E. Frelich. 2018. Interspecific competition limits the realized niche of black ash along a waterlogging gradient. Can. J. For. Res. 48: 12921301.

McCune, B., J.B. Grace and D.L. Urban. 2002. Analysis of Ecological Communities. MjM Software Design, Gleneden Beach, Oregon, USA.

Newcomb, L. 1977. Newcomb's Wildflower Guide. Little Brown Company, Boston, USA.

Niinemets, U. and F. Valladares. 2006. Tolerance to shade, drought, and waterlogging of temperate Northern Hemisphere trees and shrubs. Ecological Monographs 76: 521-547.

Oliver, C.D. and B.C. Larson. 1990. Forest Stand Dynamics. McGraw-Hill, NY. USA.

OMNRF. 1998. (Ontario Ministry of Natural Resources and Forestry). A silvicultural guide for the tolerant hardwood forest in Ontario. Ontario Ministry of Natural Resources. Queen's Printer for Ontario. Toronto, Canada.

OMNRF. 2015. (Ontario Ministry of Natural Resources and Forestry). Forest Management Guide to Silviculture in the Great Lakes St-Lawrence and boreal Forest of Ontario. Queens Printer for Ontario. Toronto, Canada. Available from: https://www.ontario.ca/ document/forest-management-guide-silviculture-great-lakes-stlawrence-and-boreal-forests-ontario- 0

Palik, B. J., A. D'Amato and R.A. Slesak. 2021. Wide-spread vulnerability of black ash (Fraxinus nigra Marsh.) wetlands in Minnesota USA to loss of tree dominance from invasive emerald ash borer. Forestry: An International Journal of Forest Research 94(3): 455-463.
Palik, B.J., M.E. Ostry, R.C. Venette and E. Abdela. 2011. Black ash (Fraxinus nigra) dieback in Minnesota: Regional variation and potential contributing factors. For. Ecol. Manage. 261(1): 128-135.

Palik, B.J., M.E. Ostry, R.C. Venette and E. Abdela. 2012. Tree regeneration in black ash (Fraxinus nigra) stands exhibiting crown dieback in Minnesota. For. Ecol. Manage. 269: 26-30.

Rowe, J.S. 1972. Forest Regions of Canada. Fisheries and Environment Canada, Canadian Forest Service, Ottawa. 172 p. Available from: http://www.cfs.nrcan.gc.ca/publications/?id=24040

Sims, R.A., H.M. Kershaw and G.M. Wickware. 1990. The Autecology of Major Tree Species in the North Central Region of Ontario; COFRDA Report 3302, Forestry Canada: Sault Ste. Marie Publisher: Ottawa, ON, Canada.

Slesak, R.A., C.F. Lenhart, K.N. Brooks, A.W. D'Amato and B.J. Palik. 2014. Water table response to harvesting and simulated emerald ash borer mortality in black ash wetlands in Minnesota, USA. Can. J. For. Res. 44: 961-968.

Speer, J.H. 2010. Fundamentals of tree-ring research. University of Arizona Press, Tucson, USA.

Springer, A. 2019. Multivariate Approach to Describing the Regeneration Niche of Black Ash (Fraxinus nigra Marsh.) in the Great Lakes - St. Lawrence Forest. MESc Thesis, Nipissing University, North Bay, ON, Canada.

Stokes, M.A. and T.L. Smiley. 1968. An Introduction to Tree-Ring Dating. University of Chicago Press, Chicago: Illinois, USA.

Tardif, J., and Y. Bergeron. 1999. Population dynamics of Black ash in response to flood-level variations, in northwestern Quebec. Ecological Monographs 69(1): 107-125.

Tardif, J., S. Dery and Y. Bergeron. 1994. Sexual regeneration of black ash (Fraxinus nigra Marsh.) in a boreal floodplain. American Midland Naturalist 132(1): 124-135.

Telander, A.C., R.A. Slesak, A. D'Amato, B.J. Palik, K.N. Brooks and C.F. Lenhart. 2015. Sap flow of black ash in wetland forests of northern Minnesota, USA: Hydrologic implications of tree mortality due to emerald ash borer. Agricultural and Forest Meteorology 206: 4-11.

Topp, G.C. 1993. Chapter 51: Soil Water Content. In: Carter, M.R. (Ed.), Soil Sampling and Methods of Analysis. Lewis Publishers, Boca Raton, FL, USA. pp. 541-558.

Townshend, E. 2012. Black ash stand dynamics and flooded jellyskin potential habitat quality in rich hardwood swamps of the Great Lakes St. Lawrence forest region. BSc Thesis Nipissing University. Nipissing University, North Bay, Ontario, Canada.

Ward, K., M. Ostry, R. Venette, B. Palik, M. Hansen and M. Hatfield. 2006. Assessment of black ash decline in Minnesota. Proceedings of the eighth annual forest inventory and analysis symposium. USDA Forest Service General Technical Report, WO-79: 115-120. Yamamoto, S. I. 2000. Forest gap dynamics and tree regeneration. J. For. Res. 5(4): 223-229. 